\title{
Plexin Domain-Containing Protein 1
}

National Cancer Institute

\section{Source}

National Cancer Institute. Plexin Domain-Containing Protein 1. NCI Thesaurus. Code C104092.

Plexin domain-containing protein $1(500 \mathrm{aa}, \sim 56 \mathrm{kDa})$ is encoded by the human PLXDC1 gene. This protein is involved in endothelial tube formation. 